\title{
“A Profecia ou O Mistério da Morte de Tut-Ank-Amon" (1924) \\ de Fernando de Carvalho Henriques. \\ Ecos literários em Portugal da descoberta do túmulo de Tutankhamon
}

\author{
José das Candeias Sales \\ Universidade Aberta; CHUL \\ Susana Mota \\ CHAM, FCSH, Universidade NOVA de Lisboa
}

Resumo: No âmbito da nossa investigação no campo da Recepção da Antiguidade em Portugal dedicada à identificação, recolha e análise de notícias e artigos sobre a descoberta do túmulo do faraó Tutankhamon publicados entre 1922 e 1939 nos jornais e revistas portugueses, deparamo-nos com um romance editado em Lisboa, em 1924, da autoria de F. de Carvalho Henriques, intitulado A Profecia ou O Mistério da Morte de TutAnk-Amon. Na narrativa principal do romance (desenvolvida nos capítulos I, VI-XIV), o Autor encaixa uma narrativa (capítulos II-IV) sobre "factos da antiguidade" para os quais mobilizou "conhecimentos históricos" sobre o antigo Egipto da época de Tutankhamon, suscitados pela então recente descoberta do túmulo desse faraó egípcio (KV 62), em Luxor ocidental, por Howard Carter, datada oficialmente de 4 de Novembro de 1922. Trata-se do primeiro romance, com contornos de policial, publicado a nível internacional inspirado nesta grande descoberta arqueológica egípcia. Não se conhecem as fontes primárias ou secundárias que F. de Carvalho Henriques utilizou para compor os capítulos II-IV do seu romance. Não se conhecem as suas leituras historiográficas sobre a época de Tutankhamon (XVIII dinastia). Não se conhece o seu efectivo entendimento sobre todos os tópicos inseridos na sua novela. Uma coisa, porém, é certa: os seus conhecimentos históricos sobre o Egipto antigo são genericamente bem sustentados, aprofundados, como procuraremos demonstrar, e 
provam como os ecos das longínquas escavações egípcias inspiraram e estimularam a imaginação de um ilustre desconhecido português e, através deste, dos seus leitores.

Palavras-chave: Fernando de Carvalho Henriques, Romance, Mistério, Tutankhamon, Recepção da Antiguidade

\begin{abstract}
In the scope of our research on the field of the Reception of Antiquity in Portugal dedicated to the identification, gathering and analysis of news and articles concerning the discovery of the tomb of the pharaoh Tutankhamon publish between 1922 and 1939 on the Portuguese newspapers and magazines, we come across a novel published in Lisbon in 1924, written by Fernando de Carvalho Henriques entitled A Profecia ou o Mistério da Morte de Tut-Ank-Amon. The main storyline of the novel (developed in the chapters I, VI-XIV), the author fit in a story (in the chapters II-IV) about "antiquity facts" to which he used "historical knowledge" about the ancient Egypt of the period of Tutankhamon, inspired by the late discovery of the tomb of that Egyptian pharaoh (KV 62) by Howard Carter in western Luxor, officially dated $4^{\text {th }}$ of November of 1922. Sharing some features with the thriller genre, it is the first novel ever published internationally inspired by the great Egyptian archaeological discovery. We do not know the primary or secondary sources that were used by F. de Carvalho Henriques to write the chapters II to IV of his novel. We do not know his historical readings about the period of Tutankhamon (18 $18^{\text {th }}$ dynasty). We do not know his actual knowledge about all the themes that compose his novel. But we do know one thing: his historical knowledge regarding the ancient Egypt is broadly well sustained, thorough, as we intend to demonstrate, and it prove that the echoes of the distant Egyptian excavations inspired and stimulated the imagination of an illustrious unknown Portuguese, and, through him, his readers.
\end{abstract}

Keywords: Fernando de Carvalho Henriques, Novel, Mystery, Tutankhamon, Reception of the Antiquity

No âmbito da nossa investigação no campo da Recepção da Antiguidade em Portugal dedicada à identificação, recolha e análise de notícias e artigos sobre a descoberta do túmulo do faraó Tutankhamon publicados entre 1922 e 1939 nos jornais e revistas portugueses, deparámo-nos com um romance editado em Lisboa, em 1924, pela Imprensa Libanio da Silva, da autoria de Fernando de Carvalho Henriques, intitulado A Profecia ou $O$ Mistério da Morte de Tut-Ank-Amon. Trata-se da primeira obra deste Autor, que poderemos 
catalogar como romance/policial-histórico e que merece, em nossa opinião, um tratamento específico, aprofundado.

Neste texto procuraremos, por um lado, dar a conhecer, através de uma breve biobibliografia, um Autor que, apesar das diversas obras publicadas ao longo dos anos, é um ilustre desconhecido do panorama literário português e, por outro lado, apresentar uma análise da obra acima mencionada, com um enfoque principal na vertente histórica de que se reveste.

\section{O Autor}

Fernando Val do Rio de Carvalho Henriques, ${ }^{1}$ nasceu nos Anjos, em Lisboa, a 17 de Dezembro de 1897, primeiro filho² de Alberto Pedro de Carvalho Henriques (02.11.187413.12.1962) e Aurélia Quaresma d'Oliveira Val do Rio (26.11.1879-15.02.1950). Não temos dados sobre onde frequentou o ensino primário, mas sabemos que, com 15 anos, a 12 Junho de 1912, fez o exame de entrada no Liceu Camões, que frequentaria até 10 Julho de 1917, altura em que, com 20 anos, concluiu os estudos liceais através do Exame do Curso complementar de Sciencias, aprovado com 12 valores. ${ }^{3}$ Nos anos lectivos de 1917/18 e 1918/19, frequentou o Curso Geral no então recém-criado Instituto Superior Técnico. ${ }^{4}$

A 25 de Novembro de 1920, Carvalho Henriques casou-se com Maria do Carmo Libânia Gonzalez de Jesus (30.01.1899-29.12.1992), a quem dedica A Profecia, e de quem teria duas filhas: Maria do Pilar de Jesus de Carvalho Henriques (16.08.1921-1995?) e Maria Aurélia de Jesus de Carvalho Henriques (06.10.1923-07.11.2011). ${ }^{5}$

Pouco sabemos sobre a sua vida profissional. No documento do Processo de liquidação do imposto sobre sucessões e doações do seu pai, em 1953, é dito que ele seria 'empregado no comércio', o que faz sentido tendo em conta que esta era a área de actividade não só do seu pai, mas da sua família de um modo geral, e que, pelo menos, duas das suas obras técnicas visam o sector comercial. ${ }^{6}$ No entanto, no testamento que redigiu em 1940, que consta no Processo de liquidação do imposto sobre sucessões e doações instaurado após a sua morte, é identificado como 'proprietário'.7 Assim, parece não ter exercido enquanto engenheiro, mas não fica claro qual seria, exactamente, a sua ocupação 
profissional. Sabemos, no entanto, que, devido principalmente à sua família materna, teria disponibilidade financeira que lhe permitia ser um homem viajado e de grande cultura.

A única fotografia que foi possível identificar (Fig. 1) demonstra, igualmente, que se movia nos meios empresariais nacionais ao estar presente, em 1935, no jantar de despedida de C.S. Brewster, Director da Vacuum Oil Company em Portugal, e de sua esposa. ${ }^{8}$

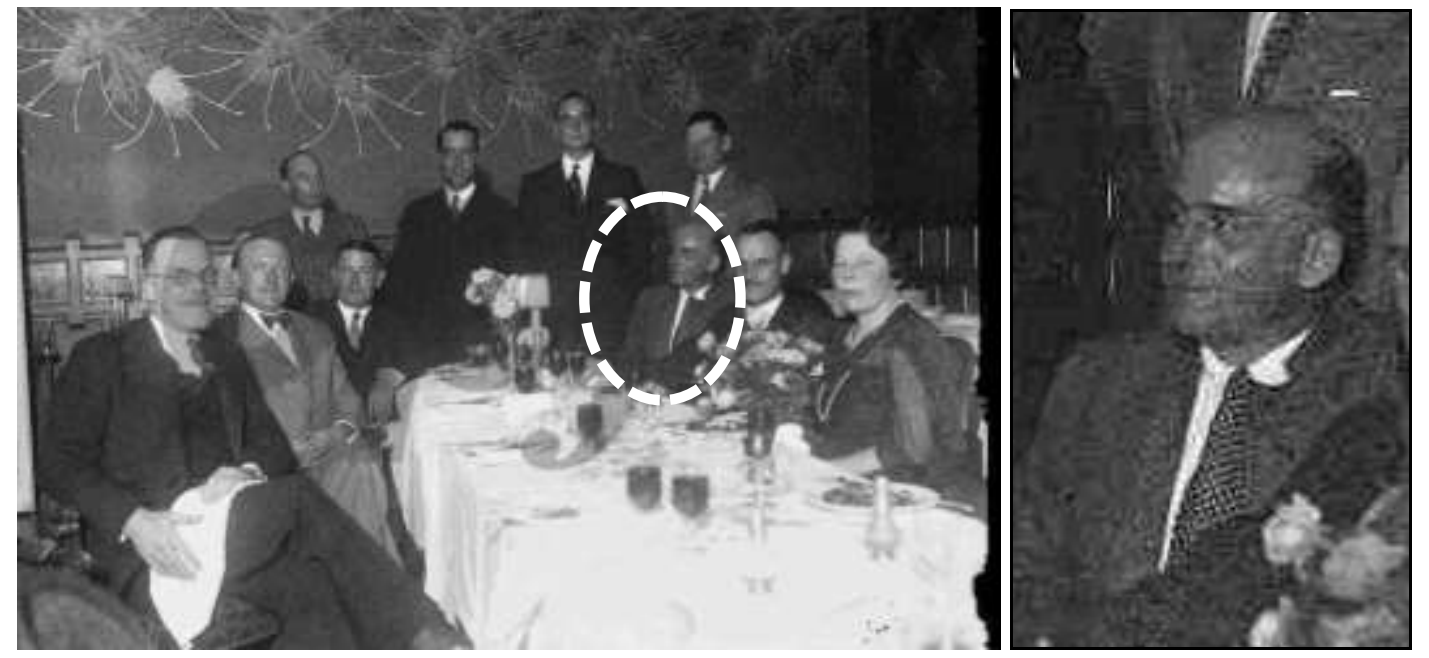

Fig. 1: Jantar de despedida do Director da Vacuum Oil Company em Portugal. Ampliação com imagem de Fernando Val do Rio de Carvalho Henriques.

A sua carreira de escritor começou, ainda em 1920, com a publicação da obra “Cuidado! Perigo de Morte. Como se evitar os acidentes de que se pode ser vitima a todo o momento dentro e fora de casa". De acordo com o blog https://casadotinoni.blogspot.com, o único local onde foi possível encontrar informação sobre este livro: “O autor, F de Carvalho Henriques, trata dos seguintes temas: evitar os riscos da electricidade, das trovoadas, da TSF, do gás iluminante, incêndios, envenenamentos e outros acidentes vulgares."9

A Profecia ou $O$ Mistério da Morte de Tut-Ank-Amon foi a sua primeira obra literária publicada, embora não seja a primeira que escreveu. Tal como menciona no prefácio e no final de Mulheres de hoje...coração de sempre, este foi, de facto, o primeiro livro que escreveu, no "Verão de 1922", mas só seria publicado no final de 1924, já depois de $A$ Profecia. 
FERNANDO de Carvalho Henriques, que T ainda ha pouco publicou uma novela nctavel $\rightarrow$ A profecia ou o misterio da morte de Tut-Ank-Amon, вcaba de lançar no merzado uma outra - Malheres de hoje... Coraçấo de semprc,

A edição, quo é elegantiasima, com uma cepa e ur hors-texte de Almeida Azevedo, ó digna do texto - uma historia sentimental dislogada, atravez da qual Maria Terezo, Jeance e Grace dialogam com proficiepcia sobre os acontecimentos do seu coreção.

Fig. 2: Notícia sobre a publicação de Mulheres de hoje... coração de sempre no Diário de Lisboa (08.12.1924, p.1).

No âmbito das obras literárias de sua autoria são ainda conhecidas: A Quarta Dimensão ou $A$ tragédia fisiológica (1927) e $O$ amigo fiel e o Fiel amigo (1960). São-lhe ainda atribuídos $A$ Montanha da Lua e $O$ oitavo pecado mortal, embora se desconheçam as datas de publicação.
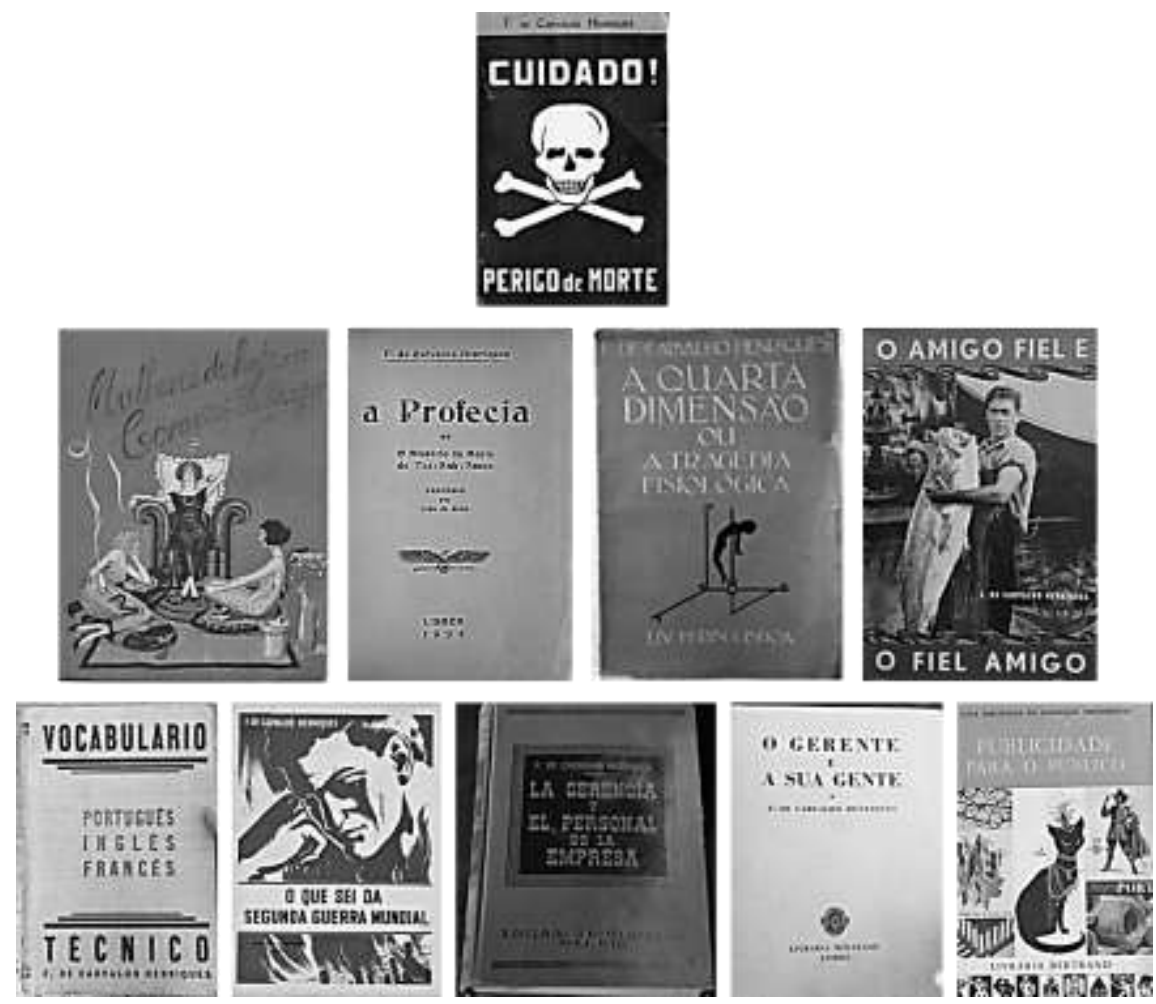

Fig.3: Algumas das obras publicadas por F. de Carvalho Henriques. 
No campo dos livros técnicos e trabalhos relacionados com o comércio, é possível arrolar vários títulos: Vocabulário Técnico: Português-inglês-francês: Técnologia Mecânica = Technical Vocabulary: English-portuguese-french: Mechanical Technology = Vocabulaire Technique: Français-portugais-anglais: Technologie Mécanique (1925), o que sei do que li e ouvi da Segunda Guerra Mundial: 100 exercícios para cada um avaliar o que sabe do primeiro ano da guerra (1941), Vendedores e Compradores: Noções de Psicologia Aplicada à Arte de Vender (1943) e O Gerente e a Sua Gente: As Relações Entre Dirigentes e Dirigidos Como Factor de Eficiência da Empresa (1946). Nesta lista deve ainda constar o livro Publicidade Para o Público, mas desconhecemos a data de publicação.

Um dado curioso em relação aos dois trabalhos literários de 1924 foi o facto de os ter oferecido ao conhecido poeta, escritor e tradutor Fernando Pessoa (1888-1935), ambos com dedicatória pessoal. Conhece-se, realmente, uma carta de Fernando Pessoa, datada de 07.01.1925, agradecendo a oferta de Mulheres de hoje... A relação entre ambos não seria muito estreita, pois o poeta trata-o nessa ocasião por “V.Exa.” (Pessoa 1999: 72-73; Martins 2008: 325). Isso não impediu que F. de Carvalho Henriques lhe tenha voltado a oferecer, em Fevereiro de 1925, um exemplar de A Profecia, hoje guardado na Casa Fernando Pessoa, onde se pode ver no frontispício a seguinte nota de oferta manuscrita: "Ao Sr. Fernando Pessoa com muita simpatia. Of. F. de Carvalho Henriques. Fevọ, 1925". Nesta "relação" com F. Pessoa, é de mencionar que F. de Carvalho Henriques dirigiu, em 1925, a X: Revista de Informação Prática (de que se publicou apenas um número, em Abril) que poderá ter influenciado Pessoa e o seu cunhado Francisco José Caetano Dias (1897-1969), marido da irmã mais velha de Pessoa, Henriqueta Madalena Nogueira dos Santos Rosa (1896-1992), no seu projecto da Revista de Comércio e Contabilidade. ${ }^{10}$

\section{A Profecia ou $O$ Mistério da Morte de Tut-Ank-Amon}

A Profecia ou O Mistério da Morte de Tut-Ank-Amon foi concluído em junho-julho de 1923, consoante apontamento inserido no final do romance, e teve um prefácio, de três páginas e meia, datado de 5 de Dezembro de 1923, assinado por João de Brito (1878- 
“A Profecia ou O Mistério da Morte de Tut-Ank-Amon" (1924) de Fernando de Carvalho Henriques.

1947). ${ }^{11}$ O prefaciador, antigo professor do Autor no Liceu Camões, considera que o romance

versa um tema filosófico que tem sido uma das preocupações constantes do espírito humano, o destino desta energia que em nós vive sob o nome de alma, depois daquilo que chamamos a morte do indivíduo, $e$ mostra-se adepto fervoroso da teoria que admite o renascimento das almas em novos indivíduos aos quais imprimem um caracter semelhante ao daqueles cuja vida anteriormente animaram, até que, volvidos muito séculos, elas encontrem numa felicidade eterna de indestrutível amor o têrmo daquela ansiedade, que aflige e tortura o espírito humano sempre insatisfeito durante a vida terrena. (p. 9).

Embora admita que esta doutrina possa não ser aceite por todas as pessoas, o Prof. João de Brito reconhece que o seu antigo aluno "obedeceu a um princípio filosófico que orienta a sua obra, tornando-a duma beleza moral indiscutível" (p. 10) e que a revestiu de originalidade, pureza de vocabulário e honestidade, "entrelaçando factos da antiguidade e dos modernos tempos", procurando "conhecer uns e outros com tão escrupulosa perfeição dentro daquilo que a história tem estabelecido como certo, que ninguém poderá dizer que êle não tenha buscado a verdade e a conveniência literárias, com elas devem ser entendidas” (p. $10,11) \cdot 12$

Os "factos da antiguidade...dentro daquilo que a história tem estabelecido como certo" que Fernando de Carvalho Henriques mobilizou para o seu romance são os "conhecimentos históricos" sobre o antigo Egipto da época do faraó Tutankhamon, suscitados pela então recente descoberta do túmulo desse faraó egípcio (KV 62), em Luxor ocidental, por Howard Carter, datada oficialmente de 4 de Novembro de 1922, que não só fornecem mote directo para a segunda parte da epígrafe do título ( $O$ mistério da morte de Tut-Ank-Amon), como para a narrativa e designações dos capítulos II (A Profecia, pp. 29-40), III (- Faraó?!... Para quê?..., pp. 40-51) e IV (Mulher! Tirar-lhe-hás a vida ao dar-lha!, pp. 52-61), que constituem, no fundo, o núcleo central motriz do romance.

A Casa Editora/ tipografia (Imprensa Libanio da Silva) ${ }^{13}$ ou o próprio Autor (considerando que se trata de uma edição de autor) ou ambos, compreendendo claramente o peso da dimensão egiptológica ou egipcianizante na obra, usou/ usaram um apelativo 
motivo iconográfico egípcio no frontispício: a representação de um abutre, chamado pelos antigos Egípcios nerau, agarrando símbolos de eternidade com as suas fortes garras. Residente familiar dos céus egípcios, o abutre (Gyps fulvus), ave provida de poderosas garras, pescoço descarnado e recurvado, olho agressivo, longo e adunco bico, forneceu a representação alada ideal para uma deusa egípcia que se considerava a "Senhora do céu meridional", a deusa Nekhebet. Segundo a concepção egípcia, os edifícios religiosos estavam impregnados de simbolismo cósmico (eram microcosmos, realizações em miniatura da ordem do universo) e os tectos das salas hipostilas dos templos simbolizavam o céu e era aí, na parte inferior dos lintéis, que eram representados conjuntos de estilizados e coloridos abutres planando (Wilkinson 2000: 76, 225; Farias 2002: 25, 27; Arnold 2003: 235; Shafer 2005: 8).

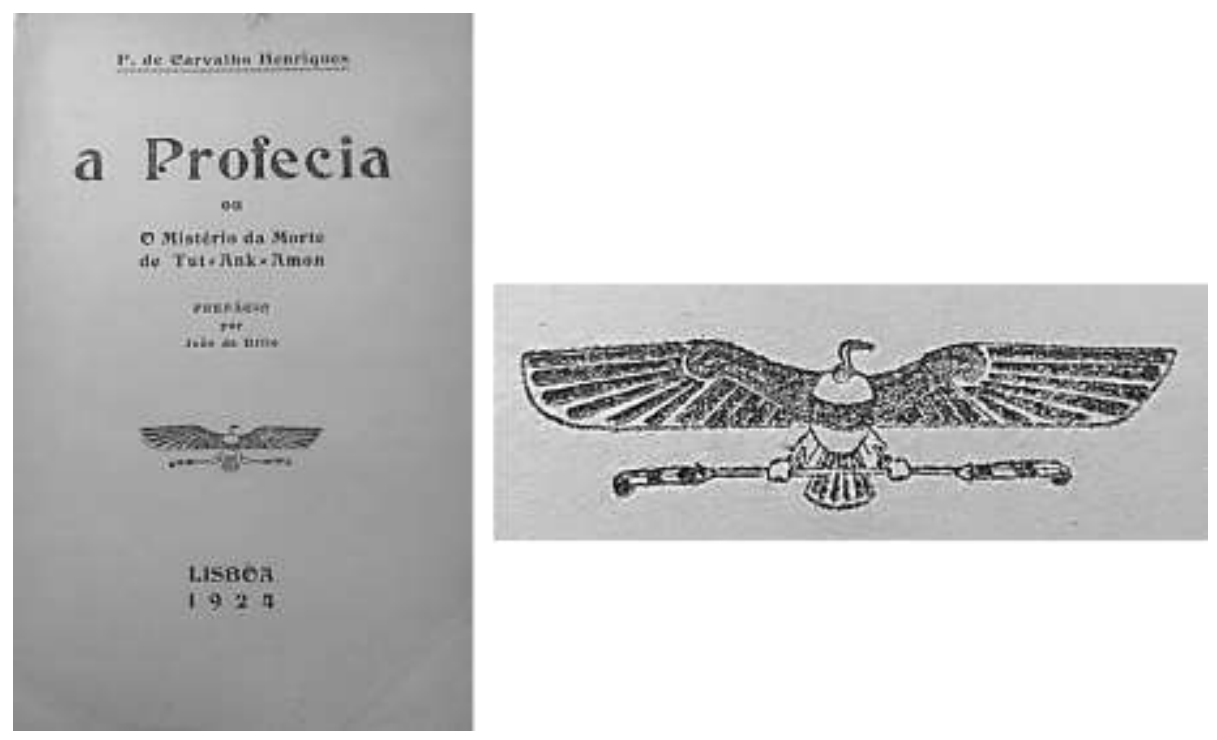

Fig. 4: Imagem completa do frontispício da obra A Profecia e ampliação da representação do nerau.

A imagem escolhida para o romance de Fernando de Carvalho Henriques imita essas representações, colhida provavelmente em alguma obra da especialidade consultada, remetendo visualmente os leitores para a cosmovisão egípcia, enfatizando, assim, com o simples pormenor desenhado de abertura do livro, o que o conteúdo literário também procurava expressar. A ilustração, como metatexto não-verbal, cria uma atmosfera, 
estabelece um fundo eficaz, para a mensagem que se pretende transmitir. Primeiro indício inteligente de "escrupulosa perfeição"...

\section{Tempo e espaço da diegese, tempo do discurso}

O livro de Fernando de Carvalho Henriques tem, no total, 150 páginas (pp. 13-162), contendo 14 capítulos. 0 conjunto de acções que formam a narrativa principal decorre nos "modernos tempos", isto é, no século XX (se quisermos ser mais exactos, na época contemporânea ao Autor, nos anos 20). O tempo e espaço da diegese são, pois, contemporâneos dos da narração do romance, ou seja, os acontecimentos são descritos como se estivessem acontecendo no presente.

Em termos de estrutura, estamos perante um trabalho que encaixa na narrativa principal um conjunto de dados sobre a história do antigo Egipto ("os factos históricos" acima mencionados). A diegese da narrativa principal, desenvolvida por uma articulação de encadeamento, abrange os capítulos I e VI a XIV. Nela encaixada surge a história passada no Egipto antigo que ocupa os capítulos II a V ou, com maior exactidão, II a IV.

Discursivamente, o Autor relata acontecimentos passados, essenciais para a compreensão da acção da narrativa principal por ele urdida. A interrupção cronológica introduzida no romance pelos capítulos II-IV, qual analepse, é um processo essencial na explanação deste trabalho de Fernando de Carvalho Henriques. É esse recuar ao Egipto antigo, portanto, condensado em 36 páginas (pp. 29-64), passado "em Tebas há trinta e três séculos" (p. 29), que sugere o mote explicativo e a "profecia" para toda a trama da obra.

Realmente, a chamada "profecia" que comanda ambas as narrativas e que as uniformiza surge mencionada na p. 40, supostamente inscrita "em caracteres demóticos" numa das faces de um obelisco a que se encostam dois personagens da história passada no Egipto (Nefer-hotep e Ti):

Mulher! Tirar-lhe-hás a vida ao dar-lha!

Trinta e três vezes cem anos que passam

Homem! Tirar-lhe-hás a vida ao dar-lha!

Trinta e três vezes cem anos que passam 
Mulher! Homem! Chegou o vosso momento na

Terra de união para a Vida eterna!

O capítulo I funciona como apresentação da acção, nele intervindo a personagem principal (José Miguel de Oliveira) e algumas das personagens secundárias (os seus amigos Ricardo e Alberto, a mulher de "vestido branco", etc.), que depois, por ordem cronológica, é desenvolvida nos capítulos VI a XIV. A parte final do Capítulo XIV (os dois últimos parágrafos) funciona como clímax ou ponto culminante da acção. É aí que, por fim, se unem os dados das duas narrativas.

Na narrativa encaixada, o capítulo V ("Trinta e três vezes cem anos que passaram" pp. 62-64) apresenta uma feição distinta dos anteriores (II-IV): enquanto aqueles são sequências que contam "factos" ocorridos com várias personagens da Antiguidade egípcia (sobretudo o jovem Nefer-hotep e a sua amada Ti) "no ano primeiro, quarto dia do segundo mês das colheitas, do Rei do Alto e do Baixo Egipto, Filho do Sol, Nek-Kheper-Ra Tut-AnkAmon, dotado de vida eterna" (p. 29), época agitada "por revoluções de carácter religioso causadas pela heresia de Amen-hotep IV' (p. 29), este constitui, no fundo, uma breve reflexão filosófica sobre o Tempo ("E passaram os trinta e três séculos que não foram mais do que um segundo a ligar a Eternidade passada e a Eternidade futura!" - p. 62; "Foi ontem, há um segundo, há um instante que Nofer-hotep e Ti deixaram a Terra" - p. 62), o Espaço ("Sumiram-se os três mil e trezentos anos, e a Terra que o Sol arrasta na sua vertiginosa queda, continua no mesmo ponto do Infinito!" - p. 62) e o Amor ("quantas Tis, quantos Noferhotepes nasceram, se amaram, gozaram ou sofreram e morreram?" - p. 62) que fundamenta a tessitura conferida à novela.

Talvez a frase do capítulo $\mathrm{V}$ que melhor sintetiza a intenção do Autor seja: "Passageira humanidade em cujo seio a toda a hora se estão encontrando almas que já se amaram ou odiaram, que em tempos esquecidos juraram adoração ou aversão eterna, recordai-vos!" - pp. 62, 63). Neste sentido, de forma distinta do que faz nos restantes capítulos, o Autor-narrador assume no capítulo $\mathrm{V}$ uma presença heterodiegética e uma posição subjectiva omnisciente-transcendente, emitindo juízos de valor bem assertivos. As 
três páginas em questão constituem o fulcro explicativo do romance ou, como lhe chama o prof. João de Barros na segunda página do Prefácio, o "princípio filosófico" - Prefácio, p. II).

\begin{tabular}{|l|l|l|l|l|}
\hline $\begin{array}{l}\text { Narrativa } \\
\text { Principal }\end{array}$ & $\begin{array}{l}\text { Narrativa } \\
\text { Encaixada }\end{array}$ & $\begin{array}{l}\text { Narrativa } \\
\text { Principal }\end{array}$ \\
\hline Cap. I & Caps. II-IV & Cap. V & Caps. VI-XIV & $\begin{array}{l}\text { Cap. XIV } \\
\text { (dois últimos } \\
\text { parágrafos) }\end{array}$ \\
\hline Apresentação & $\begin{array}{l}\text { História e } \\
\text { profecia da da } \\
\text { época de de } \\
\text { Tutankhamon }\end{array}$ & $\begin{array}{l}\text { Breve reflexão } \\
\text { filosófica sobre o } \\
\text { Tempo, o Espaço } \\
\text { e o Amor }\end{array}$ & Desenvolvimento & Clímax \\
\hline
\end{tabular}

Tabela 1: Esquema narrativo de A Profecia ou O Mistério da Morte de Tut-Ank-Amon.

No capítulo IX, em pleno desenvolvimento da ficção subjacente ao romance, há uma passagem de extraordinário valor, quer no âmbito do objecto da nossa própria investigação quer no "encontro" intencional das duas narrativas. Na fábrica que dirige, o personagem principal, o engenheiro José Miguel de Oliveira, ${ }^{14}$ desenha no seu estirador um novo tipo de alternador, quando recebe, pela manhã, das mãos de um empregado, "um maço de correspondência e de jornais" (p. 85). Desdobrando um dos jornais e lendo os títulos das diversas notícias, em diagonal, fixou a sua atenção nas duas colunas da "secção da última hora", particularmente "no fim da segunda", no texto publicado de um pequeno telegrama:

Londres. - Dizem do Cairo que no Vale dos Reis próximo do túmulo de Ramsés VI, foi descoberto o sepulcro dum rei da XVIII dinastia, supondo-se que seja o de Tut-Ank-Amon, genro do faraó KuenAten.

Esta descoberta de grandíssimo valor arqueológico, pois que ao contrário do que até hoje tem acontecido, o sarcófago do rei parece não ter sido violado, foi devida a Mr. Howard Carter que sob os auspícios de Lord Carnarvon, desde 1906 procedia a metódicas escavações no Egipto. (pp. 86, 87) 
Não sabemos se Fernando de Carvalho Henriques "compôs" o texto do telegrama enunciado a partir da consulta de um autêntico telegrama publicado na imprensa portuguesa ou se "reproduziu" directamente um desses telegramas (Sales/Mota 2018). No corpus por nós levantado de notícias publicadas na imprensa portuguesa entre o final de 1922 (momento oficial da descoberta do túmulo de Tutankhamon) e junho-julho de 1923 (data oficial da finalização do livro de Carvalho Henriques) há apenas uma notícia (publicada em O Século, de 3 de Dezembro de 1922, p. 3, intitulada "ANTIGA TEBAS. Uma grande descoberta arqueológica") que pode ter sido lida pelo Autor ou em que se poderá ter directamente inspirado para a menção que faz no seu livro (Fig. 5). ${ }^{15}$

F. de Carvalho Henriques tem clara consciência e conhecimento da informação sobre a grande descoberta arqueológica do Vale dos Reis que circulava nos jornais portugueses na época e faz, assim, através de uma notícia de jornal, no caso um telegrama proveniente de Londres, o protagonista do seu romance entrar em contacto directo com Tutankhamon, faraó da XVIII dinastia: “Nunca ouvi falar deste faraó” (p. 87), murmura José Miguel.

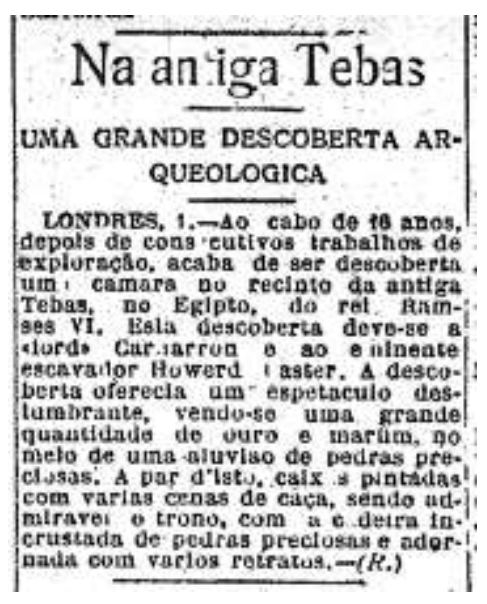

Fig. 5: Notícia publicada em O Século (03/12/1922, p. 3).

O Autor reforça o alegado desconhecimento do protagonista com alguma "falta de jeito" para os assuntos históricos, introduzindo uma nota biográfica sobre a vida escolar do 
seu herói:

É verdade que para a História tive sempre pouco geito; e sorrindo ao recordar um facto do seu tempo de liceu: - ... e foi exactamente por ter sido examinado sobre a história do Egipto que o velho Antunes, a quem alcunhavam de Boi Apis, me quis chumbar no quinto ano... (pp. 87, 88)

Para sustentar a fulcral ligação subjacente ao seu romance entre a diegese da narrativa principal e a da narrativa encaixada, Fernando de Carvalho Henriques recorre a um "fenómeno extraordinário" (p. 88): uma mosca caída no godet de tinta preta usada pelo engenheiro José Miguel para os seus desenhos técnicos, instantaneamente, "torna-se dourada" (p. 88). Mas o prodígio não se fica pela vertente da modificação cromática: junto da mosca, aparecem "uns sinais na mesma cor", circunscritos por "uma alongada elipse” (p. 88). Excepcionalmente, a estranha figura é apresentada no corpo do texto do livro sob a forma de um desenho. ${ }^{16}$

Trata-se da cartela com os signos hieroglíficos do nome de nascimento ou nome próprio do faraó Tutankhamon, numa grafia ordenada de cima para baixo, da esquerda para a direita: twt-anx-Imn HqA-Iwnw-Smai, tut-ankh-amon heka-iunu-chemai, significando "Imagem viva de Amon, governador de Heliópolis do Alto Egipto = Tebas" (Beckerath 1999: 144, 145, 12: E2). ${ }^{17}$ Paradoxalmente, para quem ignorava quem era Tutankhamon, José Miguel exclama “-Tut-Ank-Amon!..." (p. 88), não se percebendo, porém, na economia da narrativa, se está a "ler" a cartela do faraó egípcio (o que objectivamente não tem qualquer verosimilhança para quem não sabia ler os hieróglifos nem nunca ouvira falar de tal faraó...), se, depois do mágico episódio, está, ainda um pouco atordoado, a regressar, empolgado, aos pensamentos gerados pela leitura do telegrama-notícia do jornal18. Se assim for, José Miguel ficou muito impressionado com a leitura do jornal naquela manhã de Sol, pois por três vezes pronunciou o nome de "Tut-Ank-Amon" ... É isso que o Autor quer dar a perceber aos leitores. É esse o seu propósito. 


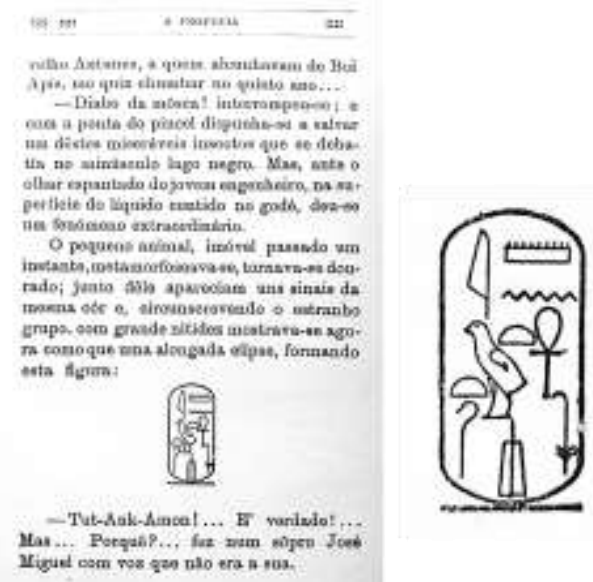

Fig. 6: Reprodução da página 88 da obra A Profecia e ampliação da cartela aí representada.

\section{"Factos da antiguidade...dentro daquilo que a história tem estabelecido como certo"}

Não se conhecem as fontes primárias ou secundárias que Fernando de Carvalho Henriques utilizou para compor os capítulos II-IV do seu romance. Não se sabe a que Autores terá recorrido para a composição histórico-ficcional com que revestiu esses capítulos. Não se conhece com total exactidão que entendimento possuía sobre todos os tópicos egípcios que inseriu na sua novela. Uma coisa, porém, é certa: os seus conhecimentos históricos sobre o Egipto antigo, sobretudo para a época de Tutankhamon (XVIII dinastia), são genericamente bem sustentados, aprofundados, como procuraremos demonstrar, não obstante uma ou outra referência mais imprecisa, incompleta ou desfasada.

Desde logo, o capítulo II começa com a localização temporal da acção recorrendo a uma habitual e correcta fórmula usada nos documentos egípcios: "Estava-se no primeiro ano, quarto dia do segundo mês das colheitas, do Rei do Alto e Baixo Egipto, Filho do Sol, Neb-Kheper-Ra Tut-Ank-Amon, dotado de vida eterna" (p. 29).

Os antigos Egípcios não usavam uma era contínua, consecutiva, partindo de uma data de referência (como os cristãos com o nascimento de Cristo ou os muçulmanos com a hégira de Maomé) para assinalarem a contagem e passagem do tempo. Na verdade, 
contavam os anos por cada faraó, separadamente, e recomeçavam sempre que um novo faraó era entronizado. Consideravam que cada reinado assinalava o recomeço da criação original e que constituía uma nova era, uma nova criação, pelo que o tempo, ou melhor, a contagem do tempo, tinha também de recomeçar de novo. A fórmula que usavam identificava o ano (renpet-hesebet), mês da estação e dia ( $s u$ ) de cada reinado, seguido do nome de coroação do faraó, permitindo, assim, datar os acontecimentos e estabelecer uma relação ou sequência entre eles. ${ }^{19}$ Apesar de ter invertido a ordem do mês e dos dias (colocando estes antes daquele), o registo de Fernando de Carvalho Henriques está correcto e confere ao capítulo II, logo a abrir, um apontamento de "busca da verdade".

A fórmula completa integra ainda referência ao rei em concreto (no caso Tutankhamon), indicando os seus nomes de trono e de nascimento do faraó, a saber, respectivamente Neb-Kheperu-Ré ("Senhor das Transformações do Sol”), introduzido pelo termo nesut-bity, "Rei do Alto e do Baixo Egipto", e Tut-Ankh-Amon ("Imagem viva de Amon"), introduzido pela designação Sa Ré, "filho de Ré" ou "Filho do Sol" (Beckerath 1999: 144, 145, 12: T1, T2 e E3; Sales 2015b: 57, 58, Leprohon 2010: 33). A estes dois nomes escritos no interior de cartelas, segue-se o epíteto di ankh djet, "dotado de vida eterna". Mesmo com os pequenos lapsos que se detectam, não há dúvida que o Autor se informou devidamente, o que não deixa de ser surpreendente face à recente descoberta do túmulo e, em consequência, ao "conhecimento histórico" válido e validado disponível.

A "infância" dos conhecimentos "certos" sobre Tutankhamon pode justificar, por outro lado, a deficiente percepção sobre as relações familiares entre Tutankhamon (c.13331323 a.C.) e Akhenaton (c.1351-1334 a.C.): ${ }^{20}$ para F. de Carvalho Henriques, Akhenaton é apenas o "sogro" de Tutankhamon. ${ }^{21}$ Embora esta afirmação esteja correcta, uma vez que Tutankhamon casou com uma filha de Akhenaton, tendo, portanto, um parentesco de "genro-sogro", hoje a maioria dos Autores prefere claramente acentuar outros elos familiares, apontando Tutankhamon como filho de Akhenaton (Dodson/Hilton 2004: 149; Reeves 2001: 161; Tyldesley 2006: 135, 136; Boot, 2007: 34, 40, 42, 44; Kemp 2012: 15; Grajetzki 2005: 62, 63). ${ }^{22}$ Observe-se, porém, que as hipóteses de filiação continuam hoje a dividir os especialistas, mesmo com o recurso a tecnologias de ponta, inexistentes na época 
de Carvalho Henriques. Era impossível ao nosso Autor afirmar ou sugerir uma ligação familiar completamente "improvável" nos anos 20 do século XX.

A terminologia usada nos capítulos II a IV para mencionar as cidades de Tebas e de Akhetaton sofre alguma flutuação, tornando-se um pouco ambígua, deixando alguma dúvida sobre a consistente identificação que F. de Carvalho Henriques estabelecia entre todas essas designações. "Tebas" (pp. 29, 34, 41, 47) também aparece como uma indecifrável "Ta-apé” (pp. 29, 51) e Akhetaton, "O horizonte de Aton", nunca é mencionada, preferindo-se “Kut-Aten" (pp. 30, 32, 33, 37, 38 - 2 x, 47, 53) ou mesmo “Tellel-Amarna” (pp. $29,41)$.

Há ainda uma outra menção geográfica feita no livro que denota alguma imprecisão/ algum desconhecimento por parte de F. de Carvalho Henriques: “...nessa época em que o Pais de Qemt estava anarquizado...". A referência é composta a partir da designação antiga que os próprios Egípcios davam ao seu pais, a saber, Kemet, "a negra” ou "a terra negra”, usando esta designação cromática para aludir ao fertilizador limo negro que se depositava sobre as terras depois da inundação anual do Nilo ${ }^{23}$. O Autor percebeu que era um sinónimo para Egipto, usando o termo "Qemt" mais duas vezes no livro (pp. 48, 50), mas não parece estar a par do seu significado...ou, pelo menos, não o explicita aos seus leitores.

Saliente-se, em contraste, que o nosso Autor tinha outros "conhecimentos certos": por exemplo, foi sensível à importante questão da mudança de nome do faraó e da sua esposa: "Nos nomes do rei e da rainha substituira-se a palavra Aten por Amon, transformando-se pois Tut-Ank-Aten e Ank-Sen-Pa-Aten respectivamente em Tut-Ank-Amon e Ank-Sen-Amon."24

De facto, o faraó subiu ao trono como Tutankhaton, "Imagem viva de Aton", tendo mudado o nome aquando do regresso à ortodoxia amoniana (Sales 2007: 167). Processo similar foi cometido para a rainha Ankhesenpaaton. Historicamente, sabemos que esta princesa era a terceira filha de Akhenaton com a sua esposa principal Nefertiti, nascida talvez por volta do seu sexto ano de reinado (Dodson/Hilton 2004: 146, 147; Lesko 1996: 20-23; Grajetzki 2005: 60, 64; Tyldesley 2006: 125, 133, 134, 137, 138; Kemp 2012: 14, 
15). ${ }^{25}$ No entanto, em $A$ Profecia, erroneamente, Fernando de Carvalho Henriques menciona-a como "a mais nova das sete filhas" (p. 36).

Percebe-se que Carvalho Henriques conhecia perfeitamente a representação iconográfica-tipo do deus Aton, pois ao relatar no seu romance o fictício ataque ao casal real Tutankhamon e Ankhseamon diz-nos que o atacante (um sacerdote de Aton) usava "uma medalha com um disco solar donde partiam raios tendo mãos nas extremidades" (p. 31). Esta é, deveras, a "imagem de marca" da representação plástica do deus-solar Aton, presente um pouco por todo o lado nas superfícies inscritas e pintadas do período amarniano. Por vezes, os raios solares terminam em mãos que seguram signos ankh ("vida") e uas ("poder") (Kemp 2012: 22, 24, 31, 42, 43, 80). Além de Aton e Amon, Carvalho Henriques mostra também conhecer várias divindades do antigo panteão egípcio, pontuando os capítulos II a IV com várias alusões de circunstância a Osíris, Set, Anúbis, Ptah, Amenit, ${ }^{26}$ Ra-HarmakuAten, ${ }^{27}$ Amon-Ré, ${ }^{28}$ Isis e Geb. ${ }^{29}$ São referências que "decoram" a composição literária, ajudando a criar a pretendida ambiência egípcia. Nesta categoria, aliás, estão também as menções a "carros" e "porta" de electrum (pp. 30 e 46, respectivamente), ${ }^{30}$ ao "espêlho de bronze" com a sua "polida superfície metálica" (p. 52), ${ }^{31}$ às "sandálias" como calçado real (p. $53)^{32}$ ou os nomes das personagens masculinas e femininas (Nefer-hotep, Ti, Hor-em-Heb, Nofritari).

Mencionámos antes que Fernando de Carvalho Henriques utiliza na p. 36 do seu livro uma nota de rodapé para traduzir o nome "Kuen-Aten"33 e na p. 48 uma outra para esclarecer o significado do nome de Tutankhamon. ${ }^{34}$ Esta última página é, aliás, extraordinária na economia da obra - um romance, atente-se - por possuir ainda mais duas notas de rodapé: uma para fornecer o significado do termo rometu e outra para explicar o que era a pschent.

"Rometu: Homem. Termo com que os egípcios se denominavam a si próprios em oposição aos estrangeiros". É assim que o termo egípcio é definido. Carvalho Henriques colheu, certamente, esta definição numa qualquer leitura, muito provavelmente num trabalho estrangeiro. Não sabemos, todavia, a que obra(s) terá recorrido. Mesmo que o termo egípcio citado esteja grafado de forma ligeiramente incorrecta (deveria ser remetju), 
não há dúvida nenhuma que a tradução "Homem" está correcta. ${ }^{35} 0$ mesmo se verifica com a explicação que fornece sobre a pschent: "A dupla côroa do Alto e do Baixo Egipto". 36

As referências a "peças de indumentária" com termos egípcios (saiote e toucado) não se ficam por aqui. Uma passagem, na p. 53, sobre o personagem-tipo Nefer-hotep, refere o saiote-chendjit e o klaft, usados pelos faraós egípcios: “...ao envergar o régio shenti ou saiote de avental triangular, e ao cobrir a cabeça com o klaft, o capuz de tecido riscado cujos pendentes ...compôs sobre o peito."37 Uma vez mais, as indicações do romancista estão genericamente correctas. Abona a favor da criatividade de F. de Carvalho Henriques esta contínua demanda de rigor nas suas descrições egípcias, sobretudo das associadas à vida de corte, dos cortesãos e altos funcionários, o que significa que houve uma pesquisa prévia e uma disposição organizada dos elementos sobre a vida no antigo Egipto investigados.

Como salientámos, a p. 48 do romance é realmente extraordinária por possuir três notas de rodapé, indiciando de forma inequívoca que o Autor recorreu a bibliografia de suporte, embora se lhe possam associar também outras quatro páginas (34, 36, 39 e 44), cada uma com a sua nota de rodapé. Também aqui, concordamos com a opinião do Prof. João de Brito no Prefácio: "escrupulosa perfeição" e genuína preocupação com os leitores, acrescentamos nós.

Na p. 36, como já se mencionou 38 , traduz "Kuen-Aten/ Amen-hotep IV". Na p. 34 explica-se o conceito de $k a$ ("O espírito sob a forma de fantasma") e na p. 44 completa-se a definição, por contraste com o ba, que se define também, escrevendo "é como que um outroeu imaterial; o Ba é o elemento vivificador que à hora da morte abandona o corpo sob a forma de ave com cabeça humana".

É muito interessante que Carvalho Henriques tenha incluído nos capítulos II e III estas alusões ao $k a$ e ao $b a$. As notas de rodapé provam a pesquisa que realizou e, simultaneamente, a sua percepção da importância destes elementos na visão antropológica e cosmológica egípcia, tanto mais que a sua narrativa confere ao tema da morte um plano de destaque.

De acordo com a visão egípcia da natureza humana, o Homem não era concebido como a combinação de vários elementos mortais e imortais, corpóreos e anímicos, físicos e 
espirituais, materiais e imateriais, mas antes como uma unidade que reunia em si todas as qualidades e características humanas que marcavam o ciclo da existência quer no Aquém quer no Além. A funcionalidade ou disfuncionalidade destes elementos ou a sua separação ou justaposição explicavam todos os grandes momentos da vida do indivíduo: a concepção, o nascimento, a morte, a mumificação, a ressurreição, a vida eterna. Esta concepção tem, portanto, enorme impacto no estudo do imaginário do antigo povo egípcio e é indissociável das suas representações sobre a vida, sobre a morte, sobre os seus costumes fúnebres, sobre a imortalidade e sobre a sua relação com o Cosmos. Carvalho Henriques intuiu a sua relevância e integrou-a na sua novela.

Entre os distintos e complementares elementos que no antigo Egipto constituíam a personalidade humana encontravam-se khet (corpo), ren (nome), ka ("duplo"), ba ("alma"), chut (sombra), akh (ser/ espírito transfigurado) e ib (coração). Cada um dos elementos traduzia uma faceta distinta do Homem que se manifestava numa certa dimensão específica e que, por isso, se tornava individualizável. Todos os elementos eram necessários, todavia, para garantir a sua existência terrena e a sua continuidade na vida extraterrena, mas talvez aqueles que maior relevância assumem são, como percebeu o nosso Autor, o ka e o ba. ${ }^{39}$

Ao relatar um sonho da jovem Ti, em que esta vê duas pirâmides, uma de ouro e uma outra verde, feita de matkat, o Autor usa duas vezes o termo na p. 39, explicando em nota de rodapé que se trata da "Malaquite". 0 termo egípcio em causa, que não está bem expresso (deveria ser mfkAt, mefkat), é hoje mais aplicado à turquesa do que à malaquite, que é conhecida como Ssmt, chesmet, ${ }^{40}$ mas a noção de verde que lhe está associada corresponde, de facto, à malaquite, carbonato básico de cobre, de cor verde e brilho vítreo polido, que se utilizava como adorno em joalharia e, em pó, como pigmento para os cosméticos e para a pintura (Shaw 2001: 10; Harrell 2012). A falha pode derivar das obras consultadas, mas mesmo assim, também aqui há uma assumida procura de plausibilidade por parte do nosso romancista na referência aos materiais e cores do mundo egípcio antigo.

Por fim, uma referência ao “dad, o emblema de Osiris, simbolo da estabilidade” (p. 45). Fernando de Carvalho Henriques está certo: havia no antigo Egipto um elemento ligado a Osíris, deus dos mortos de Mênfis (embora também surja associado a Ptah, outro deus de 
Mênfis), como símbolo da estabilidade, que era o djed ou, como também se pode designar, ded, dad ou tet. Trata-se de um dos mais antigos e comuns emblemas da mitologia egípcia. Simbolizava a estabilidade, sendo normalmente encarado como representando a coluna vertebral de Osíris (van Dijk 1986). Como amuleto, era usado por vivos e por mortos, pela crença que asseguraria a ressurreição do defunto, permitindo-lhe viver eternamente no Além. 0 pilar-djed estava associado a uma importante cerimónia ("O levantamento de djed") das celebrações do heb-sed, a festa do jubileu do faraó, por princípio celebrada no trigésimo ano de reinado, embora tal prática tenha sido constantemente desrespeitada. 0 erguer do pilar pelo faraó representava o triunfo de Osíris sobre o seu irmão-inimigo Set, assimilandose o faraó a Osíris.

É muito provável que o nosso Autor não tivesse consciência plena do significado do emblema-djed na política e na cultura do antigo Egipto, sobretudo como símbolo da vitória sobre a morte. No entanto, percepcionou a sua importância e não hesitou em incorporar este elemento na sua narrativa encaixada (cap. III).

\section{Conclusão}

A espectacular descoberta do túmulo de Tutankhamon, no Vale dos Reis, em 1922, foi um acontecimento marcante para a arqueologia egípcia que mudou para sempre a Egiptologia. 0 seu impacto, porém, não se ficou por aí. Ecos dela chegaram a Portugal e estimularam a imaginação e criatividade de homens como Fernando de Carvalho Henriques que, sob o forte impulso mobilizador que por vezes o passado gera, compôs um romance.

A imprensa portuguesa, atenta aos trabalhos de escavação que Howard Carter conduzia no Egipto, destacou esse trabalho e o seu valor. Logo no final de 1923, antes da publicação oficial do livro, o Diário de Lisboa, a 23 de Novembro, na sua p. 2, publicou um trecho da obra, remetendo directamente para o âmago da acção (a misteriosa morte de Tutankhamon), aguçando assim o interesse e a atenção dos seus leitores para essa obra, cujo título, aliás, era já bastante sedutor. Quatro meses depois, a 20 Março de 1924, já depois da publicação do romance, volta a dar-lhe destaque, com numa pequena nota: 
“Carvalho Henriques, na sua novela A Profecia ou o Mistério da Morte de Tut-Ank-Amon (...) mostrou possuir uma coisa rara nos nossos escritores - imaginação. Não se aborrecerá de certo quem ler o livro em que, com o frisson da modernidade, desvenda os mistérios do Vale do Nilo.”

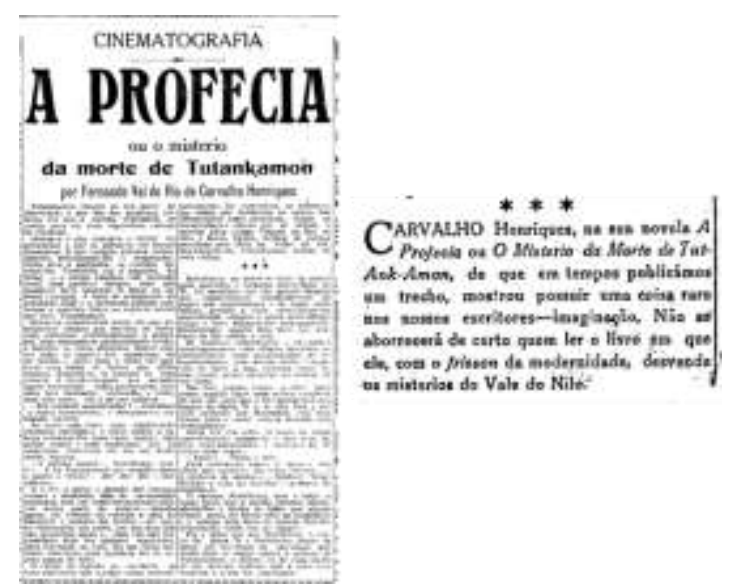

Fig.7: Notícias publicadas sobre A Profecia no Diário de Lisboa (23.11.1923, p.2 e 20.03.1924, p. 1)

"O frisson da modernidade" era a escavação no Egipto; eram, certamente, as notícias chegadas do Egipto ou de Londres sobre os trabalhos no KV 62, como hoje é conhecido, regularmente publicadas, e que os portugueses, leitores de jornais, como outros europeus, acompanhavam com natural excitação e fascínio, fantasiando, por certo, sobre as causas da morte do faraó egípcio então encontrado no seu túmulo.

Se, por um lado, F. de Carvalho Henriques era um deles, consolidando o seu gosto e interesse pela história egípcia antiga, foi, por outro lado, alguém que decidiu pesquisar mais a fundo, procurando elementos concretos sobre a vida no antigo Egipto, sobre os seus conceitos, símbolos e práticas, e canalizar os conhecimentos adquiridos para a escrita literária, fazendo um romance com contornos de policial, que conferia aos factos do passado egípcio um lugar central.

Não podemos deixar de assinalar que não só a obra de Fernando de Carvalho Henriques é ímpar no panorama nacional, como também o é, pela sua precedência, no contexto internacional. A Profecia ou o mistério da morte de Tut-Ank-Amon foi o primeiro livro publicado após a descoberta do túmulo de Tutankhamon e directamente inspirado por 
esta. Anterior a A Profecia existe apenas um 'conto' (4 páginas) de Agatha Christie, protagonizado por Hercule Poirot, intitulado The Grey Cells of M. Poirot: No. I. The Adventure of the Egyptian Tomb, publicado a 26 de Setembro de 1923, na revista londrina The Sketch. Até a autora com que compete pela primazia, faz de Fernando de Carvalho Henriques e particularmente de $A$ Profecia algo digno de nota na literatura nacional.

Fernando de Carvalho Henriques não era obviamente um historiador, nem A Profecia ou o mistério da morte de Tut-Ank-Amon era um ensaio de História, mas o seu excepcional comportamento deixou um testemunho palpável de fantasia combinada com rigor histórico que terá feito seguramente o deleite dos seus leitores como fez, quase cem anos depois, o nosso!

\section{NOTAS}

\footnotetext{
${ }^{1}$ Habitualmente assinava as suas obras como F. de Carvalho Henriques.

2 Teve dois irmãos (José Val do Rio de Carvalho Henriques e Manuel Val do Rio de Carvalho Henriques, nascidos em 1899 e 1902, respectivamente) e uma irmã (Maria de Lurdes Val do Rio de Carvalho Henriques Alves do Rio, nascida em 1901). 0 irmão, José Val do Rio de Carvalho Henriques (19.05.1899-17.01.1966) ficou conhecido pelo seu trabalho como fotógrafo.

${ }^{3}$ Agradecemos ao Arquivo do Liceu Camões, na pessoa do Dr. Francisco Pereira, pelo auxílio prestado nesta investigação e pelos dados fornecidos.
}

4 O Diário da República, № 121, de 25.05.1911, formaliza a criação do 'Instituto Superior Technico' instituindo que este era: "uma escola de engenharia". Agradecemos também ao Arquivo do IST pelos dados facultados.

${ }^{5}$ A dedicatória colocada em página ímpar, antes do índice, regista "A MINHA MULHER, para que ela dê ao livro um pouco da felicidade que me trouxe. F. de C. H." (p. 5).

${ }^{6}$ Documento existente no Arquivo do Ministério das Finanças (Processo DGCI/LIS/LIS4A/IS/12035). 
"A Profecia ou O Mistério da Morte de Tut-Ank-Amon" (1924) de Fernando de Carvalho Henriques.

${ }^{7}$ Documento existente no Arquivo do Ministério das Finanças (Processo DGCI/LIS/LIS4A/IS/16988).

8 Torre do Tombo - Arquivo do jornal $O$ Século: <https://digitarq.arquivos.pt/details?id=1018799> (último acesso em 25.06.2018).

9 Ver <https://casadotinoni.blogspot.com/2013/03/cuidado-perigo-de-morte.html> (último acesso em $24 / 06 / 2018)$

10 O capitão Caetano Dias lança e dirige a referida revista mensal em 1926, entre Janeiro e Junho (6 números), sobre temas de carácter comercial, industrial e administrativo-organizativo, de teor teórico e prático, e defendendo uma linha de liberalismo económico. Fernando Pessoa é o principal, senão mesmo o único, colaborador de todos os números publicados.

11 João de Brito, natural de Vila Real de Trás-os-Montes, foi professor efectivo do $1 \stackrel{0}{0}$ grupo, de português/ latim no Liceu Camões, em Lisboa, a partir de 1906. Em 1907, com F. A. Xavier Rodrigues, professor do Liceu Pedro Nunes, também em Lisboa, foi Autor de uma Gramática Elementar da Língua Latina para o ensino secundário que, ao longo dos anos, teria várias edições, atingindo em 1935 a sua 13a edição. Tratava praticamente todas as vertentes do estudo do Latim: fonologia e acentuação; morfologia; flexão dos substantivos; a declinação portuguesa ao lado da latina; flexão verbal; formação das palavras; sintaxe: funções dos casos (<https://archive.org/details/Gram.LinguaLatinaJoaoDeBritoEXavierRodrigues> - último acesso em 25.06.2018). 0 livro de Fernando de Carvalho Henrique de 1927, A quarta dimensão ou A tragédia fisiológica, será dedicado ao "Prof. Dr. João de Brito" que, como ele escreve, "[lhe] ensinou a converter as idéas em palavras escritas".

12 No final do "Prefácio", o Prof. Dr. João de Brito alude ao livro como "o primeiro trabalho literário" do Autor (p. 10) ou porque desconhecia a redacção anterior de Mulheres de hoje... ou porque sabia que A Profecia seria publicada primeiro.

${ }^{13}$ A empresa em questão era propriedade de Libânio da Silva (1854-?), industrial e mestre tipógrafo, autor do Manual do Tipógrafo (1908), a grande obra de referência da tipografia portuguesa, alvo de várias reedições ao longo do tempo, repleta de lições tecnológicas para os que iniciavam a sua aprendizagem na tipografia (<http://www.tipografos.net/portugal/libanio-silva.html> - último acesso em 25.06.2018).

${ }^{14}$ Repare-se que o protagonista é profissionalmente um alter-ego de F. de Carvalho Henriques, ele próprio formado em engenharia, embora não saibamos se alguma vez exerceu.

1515 Além da datação (3 de Dezembro de 1922, objectivamente cerca de quinze dias depois da descoberta oficial) e do local de proveniência dos telegramas, a nossa hipótese baseia-se em duas outras "referências textuais" da notícia de $O$ Século: a alusão ao túmulo de Ramsés VI (KV 9), situado nas imediações do túmulo 
descoberto, e aos 16 anos de escavação de Howard Carter (erradamente mencionado como "Howard Caster"), que poderia explicar a alusão ao ano de 1906 no telegrama do livro.

${ }^{16}$ Este desenho da cartela inserido a meio do romance, certamente também baseada numa qualquer obra de foro egiptológico consultada, conjuga-se com a representação desenhada do abutre do frontispício para a criação de uma atmosfera egipcianizante, enigmática, misteriosa, propensa à transmissão e assimilação da mensagem subjacente ao romance. 0 próprio "subtítulo" escolhido por F. de Carvalho Henriques para o seu "primeiro" livro realça justamente esta dimensão de "mistério". Somos capazes de imaginar o impacte sobre os leitores...

${ }^{17}$ Há quem traduza a segunda parte do nome de nascimento de Tutankhamon de outra forma: "Governador de Heliópolis do Sul”, referindo-se, contudo, na mesma, à cidade de Tebas, onde se situou a capital do jovem faraó (Leprohon 2013: 106).

${ }^{18}$ Repare-se que a transcrição do nome do faraó não grafa correctamente o segundo elemento (ankh, "vida"), provavelmente porque Fernando de Carvalho Henriques, não conhecendo as regras da escrita hieroglífica, preferiu uma leitura "fonética" que resultava mais fácil em português, aliviando o dígrafo egípcio $k h$ do $h$. Mesmo que tenha consultado obras de autores estrangeiros onde esse aspecto poderia aparecer expresso, não foi sensível a esta particularidade da onomástica do faraó da XVIII dinastia, que, aliás, também não se observa na segunda parte do título do livro. Já o mesmo não se pode dizer da tradução: na p. 48, usa "Imagem viva de Amon", colocando uma esclarecedora nota de rodapé: "Significação do nome Tut-Ank-Amon".

${ }^{19}$ Segundo a concepção egípcia, fôra o deus Tot que dividira o ano (renpet) em três estações (ter) e 12 meses (abed), cada um com 30 dias (heru), dando o seu nome ao primeiro mês do calendário egípcio. Aos 360 dias do ano acrescentavam-se mais 5 dias epagómenos, suplementares (heriu renpet). As três estações eram Akhet (período da inundação), Peret (época das sementeiras) e Chemu (época das colheitas). - Sales 2001a: 165, 166; 2001c: 255, 256; 2015a: 21-23; Allen 2004: 103- 106; Hornung et alli 2006: 47, 49.

20 Trabalhamos aqui com as datações de reinado propostas por Beckerath (1999: 286).

${ }^{21}$ É preciso salientar que a designação Akhenaton nunca aparece no livro. 0 Autor prefere "Amen-hotep IV" (p, 29, 30) ou "Kuen-Aten" (pp. 36, 85). Neste último caso, introduz uma nota de rodapé para indicar que se trata de "Amen-hotep IV". No ano 5 do seu reinado, Amenhotep IV mudou o seu nome para Akhenaton, assinalando, assim, uma profunda alteração do rumo religioso-político do Egipto antigo (Sales 2007: 165). Fernando de Carvalho Henriques entende que Amenhotep IV e Akhenaton são a mesma figura histórica, mas não avança nenhuma explicação para esta alteração de nome.

${ }^{22} \mathrm{O}$ estudo do ADN de determinados membros da família real amarniana parece demonstrar que Tutankhamon não era filho de Nefertiti nem de Kiya (as duas esposas mais conhecidas de Akhenaton), sendo 
que o seu pai poderia ser a múmia do KV 55 (Akhenaton) e a mãe a múmia do KV35YL (uma filha do faraó Amenhotep III e da rainha Tiy, irmã de Akhenaton). Seria, portanto, fruto de um incesto, o que poderia explicar a sua débil saúde. A necrose vascular do osso ou osteonecrose (perda temporária ou permanente de irrigação sanguínea nos ossos) conjugada com uma infecção palustre (malaria tropica, $P$ falciparum) podem estar na base da sua morte e explicar as dificuldades de locomoção em vida, confirmadas pelas 132 bengalas depositadas no KV 62 e hoje expostas no Museu Egípcio do Cairo, embora certos Autores descartem o uso efectivo dessas bengalas e defendam uma utilização simbólica, como elemento de status. Os vários produtos farmacêuticos destinados à vida no Além comprovariam, segundo outros, suplementarmente, a sua precária saúde (Hawass 2010: 638-647; Rühli/Ikram 2013: 6, 10; Booth 2007: 60; Reeves 1997: 178; 2000: 161; Reeves/Wilkinson 2005: 126; Vandersleyen 1983: 97-99; PM, 1964: 581, 582; Sales 2017: 134; JuanedaMagdalena Gabelas 2010: 74-77; <https://www.osirisnet.net/tombes/pharaons/toutankhamon/ toutankhamon_01.htm> - último acesso em 25.06.2018). Não obstante, Marc Gabolde continua defender que Tutankhamon era filho de Akhenaton e de Nefertiti (Gabolde 2013: 177-203; 2002: 32-48; 1993: 29-34).

${ }^{23}$ A forte impressão cromática subjacente à designação resultava, no fundo, do poderoso contraste visual entre a kemet, "a terra negra", e a decheret, "a terra vermelha", a inóspita areia dos desertos.

${ }^{24}$ Também nestas formas presentes no livro, permanece omisso o dígrafo $k h$. A preferência pela forma "Aten" em detrimento de "Aton" incorporada no nome do faraó e da rainha pode sugerir que entre as fontes de F. de Carvalho Henriques se encontravam obras em inglês onde, ainda hoje, essa é a forma utilizada para designar o deus-Sol de Amarna (Aldred 1973; Reeves 2001; Dodson 2009; Kemp 2012; Pinch 2002: 20, 109, 110; 2004: 34; Hart 2005: 34-40). 0 seu domínio do inglês - recordem-se as obras técnicas que publicou -, ter-lhe-ia permitido, com facilidade, essa consulta.

25 As seis filhas, por ordem cronológica de nascimento, eram Meritaton, Meketaton, Ankhesenpaaton, Neferneferuaton-Tacherit, Neferneferuré, Setepenré. As três primeiras nasceram em Tebas e as restantes em Akhetaton.

${ }^{26}$ Refere-se, neste caso, à deusa-monstro Amut, "A Devoradora", animal fabuloso cujas diferentes partes do corpo mostram um crocodilo, um leão e um hipopótamo, que esperava junto da balança que o resultado da pesagem do coração viesse a condenar o morto e a constituir o seu repasto. Aspirava devorar o coração-ib dos mortos condenados e proceder à aniquilação total da sua existência no Além (Sales 1999: 358-360).

${ }^{27}$ A designação recobre aqui uma tripla forma divina solar: Ré-Harmakhis-Aton. 0 deus Harmakhis, "Hórus no Horizonte", tinha como representação mais conhecida a Grande Esfinge de Guiza, esculpida em rocha viva, perto do túmulo de Khafré (IV dinastia, Império Antigo), representando um gigantesco leão com face humana, toucado real nemes e serpente uraeus (Sales 1999: 166; Quirke 2004: 168-170), Sobre a designação "Harmaku" é justo deixar aqui um apontamento suplementar: em Mulheres de hoje, a sua obra escrita no N. 40 - 06/ 2019 | 287-320 - ISSN 2183-2242 | http:/dx.doi.org/10.21747/21832242/litcomp40v4 
“Verão de 1922, mas só publicada no final de 1924, depois de A Profecia, Carvalho Henriques inicia a narração sobre as três personagens do livro com uma referência ao Egipto, neste caso o Egipto moderno, do seu tempo, onde se alude a "Harmaku":

Maria Teresa, Jeanne e Grace são grandes amigas. Conheceram-se há anos, todas três sentadas no mesmo banco dum automóvel, durante uma excursão aos arredores do Cairo. Dado esse momento por algumas semanas não mais se separaram. Juntas subiram à pirâmide de Kufu, juntas desceram ao templo do túmulo de Kafrá. Ante a estátua colossal do deus Harmaku que, olhando por cima delas sem lhes ligar importância, serenamente sorria, Maria Teresa, Jeanne e Grace, a quem muitas vezes haviam chamado esfinges, sentiram que ser esfinge na verdade é qualquer coisa de belo e terrível ao mesmo tempo, mas sobretudo um pouco chique...” (p. 7).

Se esta passagem foi efectivamente composta no "Verão de 1922", como se data este livro no final, então enquanto Howard Carter remexia no solo do Vale dos Reis, junto da entrada do túmulo de Ramsés VI, à procura de Tutankhamon, Carvalho Henriques "andava" com as suas personagens literárias pelo Cairo, demonstrando, assim, um interesse pela história egípcia anterior à grande descoberta de Novembro de 1922... Este "pioneirismo" de feição egiptológica do nosso Autor é notável e digno de registo e permite-nos extrapolar sobre o substantivo "alimento" que, depois, a descoberta do túmulo de Tutankhamon constituiu para o seu interesse e para a sua imaginação.

${ }^{28}$ Designado "Amon-Ra" (p. 48).

${ }^{29}$ A referência a este deus, o deus-terra egípcio, surge como "Seb": "deixou também a Terra, a grande moradia de Seb" (p. 61).

300 electrum (em egípcio, Dam, djam) era uma liga natural de ouro e prata, comportando 3/4 de ouro e 1/4 de prata, que no antigo Egipto provinha do Pais de Punt (provavelmente, situado na zona da actual Somália).

310 bronze (em egípcio, Hsmn, hesemen), uma liga, de $90 \%$ de cobre e $10 \%$ de estanho, era um material extremamente duro que, com as superfícies devidamente polidas, foi usado pelos antigos Egípcios no fabrico de espelhos. Os espelhos completamente circulares eram raros. Chegaram até aos nossos dias alguns ovais ou arredondados. Muitas vezes, os seus cabos, em madeira de acácia, marfim, bronze ou ouro, em forma de um papiro de umbela aberta, representavam a deusa Hathor (rosto de mulher com orelhas de vaca).

32 Em 1922-1923, quando Fernando de Carvalho Henriques redigiu o seu livro, o KV 62 ainda não fora completamente aberto e, por isso, não se sabia das mais de 80 sandálias (Tbt, tjebet ou Tbwt, tjebut) que se encontrariam entre o equipamento funerário de Tutankhamon, como, entre outras, as sandálias de papiro (Cairo, JE 2824), de couro (Cairo, JE 2820 e JE 62685) e de ouro (Cairo, JE 60680) que o Museu Egípcio do Cairo hoje exibe, nem das várias representações ou estátuas que o mostravam usando sandálias. As sandálias tinham uma clara função prática, tendo sido, por isso, usadas pelo jovem faraó em vida. Outras, porém, como 
manifestação da categoria social e riqueza do seu detentor, tinham também uma função simbólica ou ritual e podem nunca ter sido usadas. Com elas, o faraó dominava simbolicamente os seus inimigos, pisando-os, realmente, ao colocar os seus pés directamente sobre representações dos "nove arcos" (os inimigos tradicionais do Egipto), ou, quando calçado, pisava as suas representações nos escabelos ou simplesmente por possuir sandálias com essas representações (Reeves 1990: 155, 157; Reeves/Wilkinson 1996: 43, 45; PM, 1964; 582; Veldmeijer 2011: 19-41).

${ }^{33}$ Ver nota 21

${ }^{34}$ Ver nota 18.

35 Segundo um mito egípcio, os Homens nasceram das lágrimas do deus-solar Ré. Esta explicação para a origem da Humanidade residia na semelhança das palavras egípcias rmt, remit (lágrimas) e rmT, remetj (Humanidade).

${ }^{36}$ As três principais coroas usadas pelos faraós egípcios eram a coroa branca, chamada em egípcio HDt, hedjet (uma oblonga e longa mitra usada, na época pré-dinástica, pelo rei do Sul e que fazia também parte dos emblemas usados pela deusa Nekhebet, a deusa protectora do Alto Egipto), a coroa vermelha, chamada em egípcio dSrt, decheret ou nt, net, que era, em contrapartida, ostentada pelo soberano do Baixo Egipto e pela deusa Uadjit, divindade tutelar do Baixo Egipto, e a coroa que simbolizava a união dos Dois Países, a designada pschent (do grego $\psi \chi \eta \tau$ ), apropriadamente chamada em egípcio pA-sxmty, pa-sekhemeti, "a poderosa" ou "as duas poderosas" (Sales 2001b: 241). É a esta coroa que o capítulo III de A Profecia faz ajustada menção.

37 O chendjit era o saiote real de linho, plissado, com um cinturão que delimitava a parte inferior da barriga, logo abaixo do umbigo, usado pelos faraós egípcios desde a IV dinastia, e que fazia parte dos seus emblemas de poder, distinguindo-o dos demais mortais. Não era uma peça do vestuário quotidiano, mas sim, sobretudo, de momentos especiais, como cerimónias de aparato (por exemplo, a corrida ritual e o levantamento do pilar djed). Podia ser também designado chenti. Além das coroas, muitas vezes sob elas, o faraó usava na cabeça o nemes ou klaft, porventura a mais conhecida das suas coberturas de cabeça: tratava-se de um toucado de tecido listado que lhe tapava a testa e que caía em simétricas abas sobre ombros. Nas costas, o toucado terminava numa espécie de cauda enrolada (Sales 2001b: 242).

${ }^{38}$ Ver nota 21.

39 Para muitos estudiosos, o $k a$ era o mais importante aspecto da personalidade humana egípcia, representando uma espécie de força vital e sexual, capaz de se manter actuante e dinâmica por toda a eternidade. 0 ka personificava, pois, a vitalidade do indivíduo, sendo, por isso, como que um "duplo" do homem, um "fantasma" na definição de Carvalho Henriques. Para os antigos Egípcios, o túmulo era apropriadamente a hut-ka, a "morada do ka", e o Além, a Duat, o local onde o corpo e o $k a$ se voltariam a 
reencontrar/ unir, recompondo, assim, a funcionalidade experimentada na vida do Aquém. Por seu turno, o $b a$ era um elemento do composto humano que, a partir da XVIII dinastia, nas representações iconográficas a duas ou três dimensões, era representado como uma ave imaginária (embora depois surja frequentemente um pequeno falcão), dotada de cabeça humana (como F. de Carvalho Henriques salienta), homónima do defunto, e frequentemente com braços e mãos humanas. 0 recurso a uma ave é muito feliz, uma vez que um dos principais atributos do ba era justamente a sua faculdade de se deslocar do túmulo para a luz e vice-versa, sendo, por isso, um elemento muito importante para compreender a noção egípcia de imortalidade, pois era ele que realmente a proporcionava. A sua liberdade de movimento no reino da Duat (o Além) e entre mundos (Aquém e Além) é muito bem ilustrada através do símbolo da ave com cabeça do defunto. Através da sua ave, o defunto podia viajar na barca de Ré, empoleirar-se numa árvore, refrescar-se à sombra de uma árvore sagrada, perto de um lago ou num aprazível jardim, bebendo a água da vida, "refrescando-se" com as brisas e os odores perfumados (os "doces ventos") resultantes das fumigações com incenso (senetjer) e outras essências. Embora de forma muito deficiente, o conceito tem sido traduzido sobretudo como "alma", o que, contudo, não consegue transmitir o seu significado espiritual fundamental e introduz uma distinção dualística entre corpo e alma, muito significativa noutros sistemas conceptuais-filosóficos, mas profundamente arredado da concepção antropológica egípcia. Ao contrário do $k a$, o $b a$ não era intemporal: nascia com o homem e estava "no seu sangue". A manifestação deste poder divino não excluía o corpo, antes, pelo contrário, manifestava-se através dele, nomeadamente através da sexualidade. 0 sexo pode ser visto como uma forma de o ba se manifestar (Sales 2014: 141-151; Sousa 2012: 45-52; Bolsharov 2001; Taylor 2001: 18-20; Zabkar 1975, cols. 588-589; 1968, 112; Allen 2001).

$40 \mathrm{O}$ debate sobre se o termo mfkAt, $m f k a t$, se refere à turquesa ou à malaquite permanece aberto (Aston $e t$ alli 2009: 44). 


\section{Bibliografia}

Aldred, Cyril (1973), Akhenaten and Nefertiti, New York, The Brooklyn Museum/ The Viking Press.

Allen, James P. (2001), "Ba”, in The Oxford Encyclopedia of Ancient Egypt, Vol. I, Oxford, Oxford University Press, 161-162.

-- (2004), Middle Egyptian. An Introduction to the Language and Culture of Hieroglyphs, Cambridge, Cambridge University Press.

Arnold, Dieter (2003), The Encyclopedia of Ancient Egyptian Architecture, Cairo, The American University in Cairo Press.

Aston, Barbara G. / James A. Harrell / Ian Shaw (2009), "Stone", in Ancient Egyptian Materials and Technology, Cambridge, Cambridge University Press, 6-77.

Beckerath, Jürgen von (1999), Handbuck der ägyptischen königsnamen, MÄS 49, Munique, Philipp von Verlag, Mainz.

Bolsharov, Andrei O. (2001), "Ka", in The Oxford Encyclopedia of Ancient Egypt, Vol. 2, Oxford, Oxford University Press, 215-217.

Booth, Charlotte (2007), The Boy Behind the Mask: Meeting the Real Tutankhamun, London, One World Publishing.

Dodson, Aidan (2009), Amarna Sunset. Nefertiti, Tutankhamun, Ay, Horemheb and the Egyptian counter-reformation, Cairo/ New York, The American University Press.

Dodson, Aidan / Dyan Hilton (2004), The complete royal families of Ancient Egypt, Cairo, The American University in Cairo Press.

Eaton-krauss, Marianne (1977), "The khat headdress to the end of the Amarna period", Studien zur Altagyptischen Kultur, 5, 21-39. 
Farias, Cláudia Monte (2002), "O templo no antigo Egipto: simbolismo e iconografia”, ARTIS. Revista do Instituto de História da Arte da Faculdade de Letras de Lisboa, no1, 17-19.

Gabolde, Marc (1993), “La postérité d’Aménophis III”, Égyptes I, Avignon, 29-34.

-- (2002), “La parenté de Toutânkhamon”, BSFE 155, 32-48.

-- (2013), “L'ADN de la famille royale amarnienne et les sources égyptiennes. De la complémentarité des méthodes et des résultats", ENiM 6, 177-203.

Grajetzki, Wolfram (2005), Ancient Egyptian Queens. A hieroglyphic dictionary, London, Golden House Publications.

Harrell, James A. (2012), "Gemstones”, in UCLA Encyclopedia of Egyptology, Los Angeles. <http://digital2.library.ucla.edu/viewItem.do?ark=21198/zz002czx1r> (último acesso em $24 / 06 / 2018)$

Hart, George (2005), The Routledge dictionary of Egyptian gods and goddesses., London/ New York, Routledge \& Kegan Paul.

Hawass, Zahi et al. (2006), The golden king. The world of Tutankhamun, Cairo/ New York, The American University in Cairo Press.

-- (2010), “Ancestry and Pathology in King Tutankhamun's Family”, JAMA, Vol. 303, No 7, 638-647.

Hornung, Erik / Rolf Krauss / David A. Warburton (2006), "Methods of dating and the Egyptian calendar", in Ancient Egyptian Chronology, Leiden/ Boston, Brill, 45-51.

Juaneda-Magdalena Gabelas, Manuel (2010), “Ciertas dudas sobre la verdad de la resolución del dilema genético de la familia amárnica", BIAE. Boletín Informativo de Amigos de la Egiptología, 69, 74-77.

Kemp, Barry (2012), The city of Akhenaten and Nefertiti. Amarna and its people, Cairo, The American University in Cairo Press. 
Leprohon, Ronald J. (2010), “The Royal Titulary in the 18th Dynasty: Change and Continuity", Journal of Egyptian History, Volume 3, Issue 1, 7 -45.

-- (2013), The Great Name: Ancient Egyptian Royal Titulary, Atlanta, Society of Biblical Literature.

Lesko, Barbara S. (1996), The remarkable women of Ancient Egypt, Providence, B. C. Scribe Publications.

Martins, Fernando Cabral (2008), Dicionário de Fernando Pessoa e do Modernismo Português, Lisboa, Editorial Caminho.

Pessoa, Fernando (1999), Correspondência: 1923-1935, edição Manuela Parreira da Silva, Lisboa, Assírio \& Alvim, 72-73.

Pinch, Geraldine (2002), A handbook of Egyptian mythology, Santa Barbara/ Denver/ Oxford, ABC-Clio.

Quirke, Stephen (2004), Le culte de Rê. L'adoration du soleil dans l'Égypte ancienne, Monaco, Editions du Rocher.

Reeves, Nicholas (1997), The complete Tutankhamun. The King The Tomb. The Royal Treasure, Cairo, The American University in Cairo Press.

-- (2000), Ancient Egypt. The great discoveries. A year-by-year chronicle, London, Thames \& Hudson.

-- (2004), Egyptian myth. A very short introduction, Oxford, Oxford University Press.

-- (2001), Egypt's false prophet Akhenaten, London, Thames \& Hudson.

Reeves, Nicholas / Richard H. Wilkinson (2005), The complete Valley of the Kings. Tombs and Treasures of Egypt's Greatest Pharaohs, Cairo, The American University in Cairo Press.

Rühli, Frank / Salima Ikram (2013), "Purported medical diagnoses of PharaohTutankhamun, c. 1325 BC-", HOMO - Journal of Comparative Human Biology, 1-13. 
Sales, José das Candeias (1999), As divindades egípcias. Uma chave para a compreensão do Egipto antigo, Lisboa, Editorial Estampa.

-- (2001a), “Calendário”, in Dicionário do Antigo Egipto, Lisboa, Editorial Caminho, 165-167.

-- (2001b), “Coroas” in Dicionário do Antigo Egipto, Lisboa, Editorial Caminho, 241-242.

-- (2001c), “Cronologia” in Dicionário do Antigo Egipto, Lisboa, Editorial Caminho, 255-257.

-- (2007), “O nome pessoal na civilização do Egipto antigo. A nomeação como registo memorial na temporalidade" in Estudos de Egiptologia. Temáticas e problemáticas, Lisboa, Livros horizonte, 157-168, 201, 202.

-- (2014), “A Concepção Antropológica Egípcia: Da Vida no Aquém à Existência no Além”, Gaudium Sciendi, Número 6, 131-164.

-- (2015a), “Concepção e percepção de tempo e de temporalidade no Egipto antigo" in Política(s) e Cultura(s) no antigo Egipto, Lisboa, Chiado Editora, 17-47

-- (2015b), “As fórmulas protocolares egípcias ou formas e possibilidades do discurso de legitimação no Egipto antigo" in Política(s) e Cultura(s) no antigo Egipto, Lisboa, Chiado Editora, 49-86.

-- (2017), “Doenças, medicina e magia” in Hapi. Revista da Associação Cultural de Amizade Portugal-Egipto, nº 5, Lisboa, Associação Cultural de Amizade Portugal-Egipto, Novembro 201, 105-153.

Sales, José das Candeias / Susana Mota (2018), “A Agência Radio de Alejo Carrera Muñoz: contributos para a história das agências noticiosas em Portugal (anos 20 e 30 do séc. XX)” in Revista Portuguesa de História da Comunicação, n²2, Porto, SOPCOM - Associação Portuguesa de Ciências da Comunicação, 91-107. < http://revistahc.sopcom.pt /ficheiros/20180130-jos__das_candeias_sales_e_susana_mota.pdf> (último acesso em 24/06/2018)

Shafer, Byron E. (2005), "Temples, priests, and rituals: an overview” in Temples of Ancient Egypt, Cairo, The American University of Cairo, 1-30. 
Shaw, Ian (2001), "Gems”, in The Oxford Encyclopedia of Ancient Egypt, vol. 2, Oxford, Oxford University Press, 2001, 9-12.

Sousa, Rogério (2012), Em busca da imortalidade no antigo Egipto. Viagem às origens da civilização, Lisboa, Ésquilo.

Taylor, John H. (2001), Death \& the afterlife in Ancient Egypt, London, The Trustees of the British Museum.

Tyldesley, Joyce (2006), Chronicle of the Queens of Egypt from early dynasties times to the death of Cleopatra, London, Thames \& Hudson.

Vandersleyen, Claude (1983), “Quelques énigmes éclaircies à propos de la tombe de Toutankhamon", Bulletin de la Socièté d'Égytologie, Genève, 8, 97-99.

Van dijk, Jacobus (1986), "The symbolism of the memphite djed-pillar”, OMRO 66, 7-20.

Veldmeijer, André J. (2011), Tutankhamun's footwear: Studies of ancient Egyptian footwear, Leiden, Sidestone Press.

Wilkinson, Richard (2000), The complete temples of Ancient Egypt. London, Thames \& Hudson.

Zabkar, Louis V. ((1968), A study of the ba concept in ancient Egyptian texts, Chicago, University of Chicago Press.

-- (1975), “Ba” in Lexikon der Ägyptologie I, Wiesbaden, Otto Harrassowitz, cols. 588-590. 
José Sales é Doutorado e Agregado em História Antiga, é docente na Universidade Aberta e investigador do Centro de História da Universidade de Lisboa. Desenvolve os seus trabalhos na área da História Antiga - domínio Egiptologia, tendo vários livros e artigos publicados, em Portugal e no estrangeiro, nesse âmbito. É responsável pelo projecto de investigação “Tutankhamon em Portugal. Relatos na Imprensa Portuguesa (1922-1939)” no âmbito dos Estudos da Recepção da Antiguidade, destinado a identificar, analisar e publicar as notícias publicadas na imprensa portuguesa (jornais e revistas) sobre a descoberta do tumulo do faraó Tutankhamon.

Susana Mota desenvolve, desde 2006, investigação na área da Egiptologia. Começando por trabalhar sobre o Direito e a Justiça no Egipto antigo, passou depois para a área da Religião, em particular a Religião Doméstica, na qual realizou o seu doutoramento. Presentemente, além de continuar a desenvolver trabalho relacionado com a Religião Doméstica no antigo Egipto, é co-responsável pelo projecto de investigação na área da Recepção da Antiguidade intitulado “Tutankhamon em Portugal. Relatos na Imprensa Portuguesa (1922-1939)". Este projecto visa identificar, analisar e publicar as notícias publicadas na imprensa portuguesa sobre a descoberta do tumulo do faraó Tutankhamon. Este projecto levou a que, em paralelo, desenvolvesse investigações na área da História da Comunicação. 